\title{
Missä olemme kun olemme
}

\section{suhteissa?}

Kenneth J. Gergen (2009). Relational being. Beyond self and community. Oxford University Press. $418 \mathrm{~s}$.

A merikkalaisprofessori Kenneth J. Gergen tuli 1980-90-luvuilla kansainvälisesti tunnetuimmaksi sosiokonstruktionismin edustajaksi. Hänen aiempia teoksiaan ovat muun muassa The saturated self. Dilemmas of identity in contemporary life (1991), Realities and relationships (1994) ja An invitation to social construction (1999).

Gergen on herättänyt epätavanomaisilla ajatuksillaan voimakkaita reaktioita puolesta ja vastaan. Juha Siltala käytti kymmeniä sivuja eräästä artikkelistaan osoittaakseen Gergenin vastuulliseksi lasten heitteille jätöstä ja lapsen tarvitsevuuden väheksymisestä. Yleisöä viihdyttääkseen erään konferenssin järjestäjät panivat pystyyn julkisen "kukkotappelun" pahaa aavistamattoman Gergenin ja hänen ankaran vastustajansa, filosofi John Searlen välillä. Voimille käyneen mittelön jälkeen Gergen tuskin uskalsi lähestyä Searlea, mutta Searle tuli naureskellen hänen luokseen ja totesi, että he voisivat järjestää show'n toistekin ja lyödä yhdessä rahoiksi.

Uusimmassa teoksessaan Gergen ei enää puhu konstruktionismista, vaan lainaa Martin Buberin lausahdusta "Alussa oli suhde". Valistuksen ajoilta kulttuuriimme on periytynyt käsitys erillisistä ja riippumattomista yksilöistä. Tunteet, motivaatio, järki, muisti ja kokemus sijoitetaan yksilön sisään, vaikka nämä si- jaitsevat Gergenin mukaan niissä suhteissa, joissa olemme osallisina. Merkitykset syntyvät koordinoidussa toiminnassa, kanssatoimijuudessa. Muut ihmiset eivät ole toimintamme syitä kausaalisessa mielessä. Perinteinen eristynyt yksilökäsitys johtaa vieraantumiseen, yksinäisyyteen, konflikteihin, itsensä epäilyyn, itsekkyyteen ja manipulatiivisiin suhteisiin. Tarvitaankin "uutta valistusta" (s. 403), jolloin suhteissa olo nousee arvoon yksilöllisyyden tai yksittäisten ja toisilleen vieraiden yhteisöjen sijasta.

\section{Minuus suhteissa olemisen tuote}

Suhteissa oleminen (relational being) ei tarkoita yksilöiden tai minuuksien yhdessä oloa, vaan minä tai minuus (self) on suhteissa olemisen tuote. Jo yhdessäsanan Gergen kertoo juuttuvan kurkkuunsa, koska se viittaa erillisten yksilöiden yhteen liittymiseen. Hän kiinnittääkin erityistä huomiota kielellisen ilmaisuun pyrkien pitämään mielessään Wittgensteinin huomautuksen siitä, että maailmani rajat ovat yhtä kuin kieleni rajat. Gergen ei silti halua hylätä tähänastista psykologista ja yhteiskunnallista sanastoa, vaan tulkita totunnaisia käsitteitä uudelleen ja asettaa niitä uusiin yhteyksiin. Täysin uuden sanaston luominen johtaisi selkeyden puutteeseen ja dialogin vaikeutumiseen.

Valistuksen perua on paitsi eristynyt yksilökäsitys, myös käsitys koherentista mielestä, yhtenäisestä ja johdonmukaisesta minuudesta. Gergenin mukaan olemistamme luonnehtii pikemminkin "monioleminen"(multi-being). Tämä ei tarkoita tuuliviirimäisyyttä, koska yleensä haluamme ylläpitää tietynlaista sosiaalista järjestystä, jaettuja skenaarioita. Nykyisten, menneiden tai tulevien, todellisten tai kuviteltujen suhteiden jäljet sitovat meitä erilaisiin yhdessäoloihin ja avaavat lukemattomia toiminnan mahdollisuuksia, mutta monioleminen ei takaa toiminnan johdonmukaisuutta.

Usein kuultu vastaväite moniolemista vastaan on tietoisuus kokemukset yhteen nivovasta minästä. Gergenin mukaan minätietoisuus ei poista moniolemista tai päinvastoin. Hän valaisee asiaa seuraavalla esimerkillä. Luennoidessaan hän kertoo yleensä olevansa täysin yhtä tehtävänsä, aiheensa ja kuulijoidensa kanssa. Korostunut tietoisuus itsestä veisi huomion pääasiasta. Kerran hän kuitenkin luennollaan oli unohtanut housuistaan vyön, ja housut alkoivat valua alas. Seikka lisäsi väistämättä tietoisuutta itsestä tavalla, joka siinä tilanteessa muutti suhdetta muihin, mutta ei poistanut suhteissa olemista.

Voimme ylläpitää toiminnan ennakoitavuutta ja sosiaalista järjestystä joko sivilisaatioomme kuuluvilla yleisillä skenaarioilla, kuten tervehtiminen ja terveh- 
dykseen vastaaminen, tai sitten rooli- ja kontekstisidonnaisemmin. Luomme myös jatkuvasti uusia, enemmän tai vähemmän ymmärrettäviä sosiaalisia järjestyksiä.

\section{Minä osana yhteistä virtaavuutta}

Moniolemisessa eli osallistuessamme moninaisiin suhteisiin ja kantaessamme suhteiden jälkiä olemme jatkuvan virtauksen tilassa, osana yhteistä virtaavuutta (confluence). Emme tee, muista tai ajattele paljoakaan, ellei meitä kutsuta tällaiseen toimintaan. Jollemme tavoita toisen ajatusta, kyse ei niinkään ole eläytymiskyvyn puutteesta vaan siitä, ettemme onnistu tavoittamaan skenaariota, johon toinen meitä kutsuu. Emme niinkään tunne tunteita, vaan teemme tunteita.

Paradoksaalisesti hyvälle elämälle välttämätön liittyminen erilaisiin sidoksiin - suhteisiin ja yhteisöihin - johtaa samalla yhteistä toimintaa ehkäisevien uusien rajojen pystyttämiseen meiksi ja muiksi määriteltyjen välille. Turhanaikaisia rajoja pystyttämällä aiheutamme keinotekoisia katkoksia yhteiseen virtaukseen.

Kirjassa ei jäädä yleisen julistuksen tasolle, vaan tarkastellaan varsin käytännönläheisesti, miten kasvatuksessa, psykoterapiassa, työorganisaatioissa, eri uskontojen vuoropuhelussa tai nettiyhteisöissä voidaan päästä yhteistoimintaan ja yhteiseen merkitysten luomiseen. Jotkut esimerkit ovat amerikkalaisesta yhteiskunnasta, joita ei voine sellaisenaan soveltaa täällä. Opetusalalla hän puhuu yhteistoiminnallisten menetelmien ja yhteisen tiedon rakentamisen puolesta tavalla, joka on tullut aikuiskasvattajille muista yhteyksistä tutuksi. Suomalaislukijaa ilahduttaa, kun psykoterapiaa käsittelevässä luvussa kuvataan Jaakko Seikkulan ja Tom Erik Arnkilin dialogista lähestymistapaa vaikeiksi diagnosoitujen henkilöiden kanssa.

Organisaatioita käsittelevässä luvussa esitetään tuottavuudenkin kannalta vakuuttavia case-kuvauksia dialogisen ja suhteissa olevan johtamistavan puolesta (relational leading) yksilöihin tai ryhmiin kohdistuvan johtamisen sijasta. Organisaatiot elävät kaaoksen ja järjestyksen rajoilla. Yhteistoiminnallisuus ja yhteinen virtaavuus voivat tukea sekä järjestystä, sitä mistä ollaan yhtä mieltä, että kaaosta, jolloin yhteinen luominen (co-creation) liittyy tradition muutokseen. Moniäänisyys organisaatioissa ei tarkoita vain eri ihmisten mielipiteiden kuuntelua, vaan moniäänisyyttä voi bahtinilaisittain kuulla myös yksittäisen puhujan puheessa. Jacques Derridan mukaan johdonmukaisuuteen päästään vain unohtamalla sanojen merkitysten perustavanlaatuinen epämääräisyys.

Kirjan loppupuolella keskitytään moraalisuuteen ja liikutaan pyhän ja profaanin rajoilla. Erilaisia dikotomioita purkaessaan Gergen haluaa purkaa myös jaottelun siihen, miten asiat "ovat" ja siihen, miten niiden tulisi olla. Ongelmana ei hänen mukaansa ole niinkään moraalittomuus vaan siltojen rakentaminen monien moraalisuuksien välille.

\section{Lukijassa herääviä kysymyksiä}

Kysymyksiä lukijalle herää siitä, mitä tarkoittaa suhteissa oleva vastuu (relational responsibility), jota Gergen sinänsä johdon-

mukaisesti ehdottaa perinteisen yksilöllisen vastuun sijaan. Jos vastuu ei ole yksilöillä, missä se silloin on? Voiko tällainen vastuun ulkoistaminen suhteisiin johtaa "tein vain mitä käskettiin" -moraaliin?

Akateemista kirjoittamisperinnettä Gergen ei keskustelukumppaninsa John Shotterin tavoin pidä enää lainkaan arvossa. Monologinen kirjoittaminen ja pakonomainen tieteellisten julkaisujen tuottaminen eristää toisistaan tietävän kirjoittajan ja tietämättömiksi määritellyt lukijat.

Gergenin kirjoitustapa on moniääninen, ja hän pyrkii välttämään monologisuutta myös kirjansa rakenteessa. Hän yhdistää teoriansa kehittelyyn paitsi käytännön esimerkkejä myös omaelämäkerrallista ainesta (kuten kuvaukset housujen putoamisesta tai kukkotappelusta Searlen kanssa), aforistista puhetta ja aina valppaan kriitikkonsa kommentteja. Kirjoittajan "varjo" esittää pitkin matkaa perusteltuja vastaväitteitä, joita ei ole helppo ohittaa. Näin enimmäkseen vältetään niin sanottu olkiukkoefekti eli vastakkaisen mielipiteen esittäminen niin simppelinä, että kirjoittajan on helppo kumota se itse turauttamiensa voitonfanfaarien säestyksellä.

\section{Jussi Onnismaa}

